\title{
Distribution of Mineral Substances in Different Wood Tissues of European Larch (Larix decidua Mill.)
}

\section{Raspodjela mineralnih tvari u različitim drvnim tkivima europskog ariša (Larix decidua Mill.)}

\author{
Original scientific paper • Izvorni znanstveni rad \\ Received-prispjelo: 20. 5. 2011. \\ Accepted-prihvaćeno: 9. 2. 2012. \\ UDK: $630 * 811.1 ; 630 * 813 ; 674.032 .475 .342$ \\ doi: $10.5552 /$ drind.2012.1117
}

\begin{abstract}
Typical wood tissues, such as stemwood, bark, branches, twigs and needles, of two very old European larch trees (Larix decidua Mill.) were examined for the content of macro and micro mineral substances. Elemental analysis, atomic absorption spectrophotometry (AAS) and ultraviolet/visible (UV/VIS) techniques were applied for quantitative determination of individual elements. The results indicated that both trees had almost identical mineral content. The highest contents of macro elements $\mathrm{N}, \mathrm{P}, \mathrm{S}, \mathrm{K}$ and $\mathrm{Mg}$ as well as micro elements $\mathrm{Ni}$, $\mathrm{Fe}$, Al and Co were measured in needles, while Ca, Mn and Zn prevailed in bark. Concentrations of substances were the lowest in stemwood. Comparison with similar studies of foliar mineral distribution proved that both trees had good nutrient status, which corresponded to their condition.
\end{abstract}

Keywords: European larch, micro and macro nutrients, AAS, elemental analysis, foliar mineral distribution

\begin{abstract}
SAŽETAK • U radu se prikazuju rezultati istraživanja sadržaja mikromineralnih i makromineralnih elemenata u tipičnomu drvnom tkivu dvaju stabala vrlo starih europskih ariša (Larix decidua Mill.) kao što su stablo (deblo), kora, grane, grančice i iglice. Za kvantitativno određivanje pojedinačnih elemenata primijenjene su elementarne analize, atomska apsorpcijska spektrofotometrija (AAS) i ultraljubičasta/vidljiva (UV/VIS) analitička tehnika. Prema dobivenim rezultatima, svi su usporedivi uzorci oba drva imali praktički jednak mineralni sastav. Najveći sadržaj makroelemenata $\mathrm{N}, \mathrm{P}, \mathrm{S}, \mathrm{K}$ i Mg, kao i mikroelemenata $\mathrm{Ni}, \mathrm{Fe}$, Al i Co, zastupljen je u iglicama, no Ca, Mn i Zn prevladavali su u kori. Najniže koncentracije mineralnih tvari izmjerene su u drvu stabla (debla). U usporedbi sa sličnim studijama raspodjele mineralnih tvari u iglicama, dokazano je da svi uzorci drva imaju primjeren sadržaj tih tvari, što odgovara njihovu zdravom stanju.
\end{abstract}

Ključne riječi: europski ariš (Larix decidua Mill.), sadržaj mikromineralnih i makromineralnih tvari, atomska apsorpcijska spektrofotometrija, elementarna analiza

\footnotetext{
Authors are researchers at the Pulp and Paper Institute Ljubljana, Slovenia.

Autori su znanstvenici Instituta za pulpu i papir u Ljubljani, Slovenija.
} 


\section{INTRODUCTION}

\section{UVOD}

Trees and other plants receive their nutritional elements from air, water and soil. The most basic building elements are carbon (C), oxygen $(\mathrm{O})$ and hydrogen $(\mathrm{H})$. Their sources are air and water. They combine to form higher structures such as carbohydrates, which compose plant tissues. Besides, there are at least 14 other mineral elements that are needed for the growth.

Minerals play an important role in plant metabolism. They are components of organic structures, such as proteins and nucleic acids, which are essential constituents of living organisms. They are charge carriers and osmotic regulators and serve as promoters of numerous enzymatic reactions. Their participation in the division and differentiation of cells as well as photosynthesis is also significant. In short, tree growth is in many ways dependent on mineral uptake and distribution (Fengel and Wegener, 1989; Leyton, 1957).

Most minerals are delivered to the tree from forest soil through its root system; however some can be absorbed through leaves. Total mineral contents and concentrations of individual elements vary within and between tree species and are also strongly dependent on ecological factors, i.e. the site where a tree is growing (Bujas, 1998; Antonović et al, 2007; Antonović et al, 2010). Typically, mineral contents of needles, leaves, bark, branches, twigs and roots are higher than those of stemwood. Younger trees are likely to contain higher concentrations of nutrients than mature ones and hardwoods are richer in them than softwoods. In most cases alkali and alkali earth elements such as potassium $(\mathrm{K})$, calcium $(\mathrm{Ca})$ and magnesium $(\mathrm{Mg})$ make up to $80 \%$ of the total inorganic constitution of softwoods and hardwoods. Among them $\mathrm{Ca}$ predominates constituting often up to about $50 \%$ of the total inorganics. A variety of other elements can also be detected in wood tissues, altogether about seventy, however only 17 have been identified so far as essential, meaning that plant needs them to complete its reproductive stage of life cycle. These are the above mentioned carbon (C), oxygen $(\mathrm{O})$, hydrogen $(\mathrm{H})$, potassium $(\mathrm{K})$, calcium (Ca) and magnesium $(\mathrm{Mg})$ as well as nitrogen $(\mathrm{N})$, phosphorus $(\mathrm{P})$, sulfur $(\mathrm{S})$, iron $(\mathrm{Fe})$, manganese $(\mathrm{Mn})$, zinc $(\mathrm{Zn})$, copper $(\mathrm{Cu})$, boron (B), molybdenum (Mo), nickel $(\mathrm{Ni})$ and chlorine $(\mathrm{Cl}) . \mathrm{N}, \mathrm{P}, \mathrm{K}, \mathrm{Ca}, \mathrm{Mg}$ and $\mathrm{S}$ are considered major or macro-nutrients, because they are required in large quantities that range between 1 to 150 g per kg of plant dry matter. Fe, $\mathrm{Zn}, \mathrm{Mn}, \mathrm{Cu}, \mathrm{B}, \mathrm{Mo}, \mathrm{Cl}$ and $\mathrm{Ni}$ are minor or micro-nutrients that are required in amounts from 0.1 to $100 \mathrm{mg}$ per kg of dry matter (Henry et al, 1992; Merilä and Derome, 2008; Ditmarova et al, 2007).

There is also a distinctive difference between nutrient minerals according to their mobility. Mobile nutrients are those able to move out of older plant parts to younger ones when supplies are not adequate. Mobile elements are $\mathrm{N}, \mathrm{P}, \mathrm{K}, \mathrm{Cl}, \mathrm{Mg}$ and $\mathrm{Mo}$. In contrast, immobile nutrients are $\mathrm{B}, \mathrm{Ca}, \mathrm{Cu}, \mathrm{Fe}, \mathrm{Mn}, \mathrm{Ni}, \mathrm{S}$ and $\mathrm{Zn}$. Typically they cannot move quickly or not at all from one plant part to another (Stenius, 1999; Raven et al, 2005; Rowell, 2005).

The role of individual elements can be fairly well explained but not always fully. $\mathrm{N}$ is contained in all enzymes essential for plant functions, $\mathrm{P}$ is a component of ATP, a compound that supplies the energy to grow and maintain the plant, $\mathrm{K}$ activates certain enzymes and balances the charge between ions, $\mathrm{S}$ is a part of certain amino acids and all proteins, $\mathrm{Ca}$ is contained in cell walls, regulates cell wall construction and balances charge, $\mathrm{Mg}$ is the central element within the chlorophyll molecule, B is important for sugar transport within plants and plays a role in cell division, Mo is needed for the reduction of absorbed nitrates into ammonia prior to incorporation into amino acids, $\mathrm{Fe}$ is a component of many enzymes and light energy transferring compounds, $\mathrm{Zn}$ is essential for plant hormone balance, $\mathrm{Mn}$ is a cofactor in many plant reactions, $\mathrm{Cu}$ is a component of enzymes involved in photosynthesis while $\mathrm{Cl}$ is a charge balancing ion (Raven et al, 2005).

Deficiency of individual macro and micro elements results in specific growth disturbances as well as overall plant health deterioration due to the fact that essential biochemical and physiological processes are interrupted. Proportions among elements should also be balanced in order for the plant to achieve optimal uptake of all the necessary minerals (Ericsson et al, 1993; Katzensteiner et al, 1992; Mandre and Kuznetsova, 2004; Cape et al, 1990; Ingestad, 1979). Nutritional condition of a living tree can be typically evaluated by chemical analysis of needles or leaves, respectively. Less common is the evaluation based on stemwood minerals characterization (Eriksson and Rosen, 1994; Komlenovič et al, 1995; Myre and Camiré, 1996)

Total inorganics in wood can be evaluated by determination of ash content after combustion of plant material. Woods typically contain from 0.1 to $1.5 \%$ of ash, however in some tropical species these values may be exceeded. The ash is predominantly composed of different metal oxides, silicates, carbonates and other salts. Individual elements can be determined either from ash or after acidic digestion of plant material by various analytical techniques such as atomic absorption spectroscopy, colorimetry and elemental analyses (Stelzer et al, 1993).

The aim of our research was to evaluate concentrations of different essential elements as well as cobalt and aluminum in various anatomical parts of two healthy and very old European larches in order to define variations within individual tree as well as between trees growing in the same area. The data will be useful for further studies of relations between mineral constitution, growing conditions and plant health.

\section{MATERIAL AND METHODS} 2. MATERIJAL I METODE

\subsection{Samples}

2.1. Uzorci

Two larch trees (Larix decidua Mill.) were felled at the end of June in the Alpine region of Slovenia at 
the altitude of $1000 \mathrm{~m}$. They were growing in a mixed forest among beech and spruce trees. Both were 180 years old and about $30 \mathrm{~m}$ high. They were healthy as they had good living conditions provided by rich forest soil (brown, carbonate ground).

$5 \mathrm{~cm}$ thick discs were cut from the trunks at the base (20 $\mathrm{cm}$ above ground) as well as at the heights of 8,18 and $28 \mathrm{~m}$. A living branch was taken from each tree at the height of $18 \mathrm{~m}$. A part, up to $1.5 \mathrm{~m}$ from the trunk was used for analyses. Twigs (about $0.5 \mathrm{~cm}$ wide) and needles from the same branch were also collected (about $500 \mathrm{~g}$ of each).

Discs as well as branches were debarked and cut into smaller pieces. Samples, including stemwood, branchwood, bark, twigs and needles, were frozen at $24{ }^{\circ} \mathrm{C}$ till analysis. Stemwood bark was treated as only one bulk sample, so it was not divided according to the height levels. Samples were vacuum dried at $30{ }^{\circ} \mathrm{C}$, ground to wood meal and homogenized before combustion and digestion.

\subsection{Analyses}

2.2. Analize

Ash content

All samples were analyzed for the content of ash $\left(550{ }^{\circ} \mathrm{C}\right)$ according to the DIN EN 12879 standard method.

\section{FTIR spectra}

Spectra of ash samples were recorded on BioradExcalibur spectrophotometer as transmission spectra on $\mathrm{KBr}$ pellets in the range between 4000 and $400 \mathrm{~cm}^{-1}$.

Elemental analyses

C, N and S were analyzed on CNS LECO 2000 instrument for elemental analysis, which was equipped with IR and thermoconductivity detectors.

\section{Determination of phosphorus}

$\mathrm{P}$ was determined spectrophotometrically after digestion of samples with conc. $\mathrm{H}_{2} \mathrm{SO}_{4}$ and $\mathrm{HNO}_{3}$. Concentration of $\mathrm{P}$ was measured in diluted solution according to the ISO 6878 standard (ammonium molybdate method).

\section{Determination of $\mathrm{K}, \mathrm{Ca}, \mathrm{Mg}, \mathrm{Cu}, \mathrm{Ni}, \mathrm{Co}, \mathrm{Fe}, \mathrm{Mn}, \mathrm{Zn}$,} and $A l$

Samples were digested by $\mathrm{HNO}_{3}$ and $\mathrm{H}_{2} \mathrm{O}_{2}$. Concentrations of individual elements were measured by AAS technique on Varian SpectrAA 220 instrument using electrothermal atomization for $\mathrm{Cu}, \mathrm{Ni}, \mathrm{Co}, \mathrm{Al}$ and flame ionization for $\mathrm{K}, \mathrm{Ca}, \mathrm{Mg}, \mathrm{Mn}, \mathrm{Fe}, \mathrm{Zn}$.

All analyses were performed in 3 parallels. The results are average values of individual measurements. They are expressed as $\%(w / w)$ for ash content and $\mathrm{N}$, as $\mathrm{g} / \mathrm{kg}$ for $\mathrm{P}, \mathrm{K}, \mathrm{S}, \mathrm{Mg}$ and $\mathrm{Ca}$ and as $\mathrm{mg} / \mathrm{kg}$ for $\mathrm{Cu}, \mathrm{Ni}$, $\mathrm{Co}, \mathrm{Fe}, \mathrm{Mn}, \mathrm{Zn}$ and $\mathrm{Al}$. All values are expressed per weight of dry sample.

\section{RESULTS AND DISCUSSION} 3. REZULTATI I RASPRAVA

Ash contents showed typical pattern of mineral distribution in the trees. Stemwood values increased

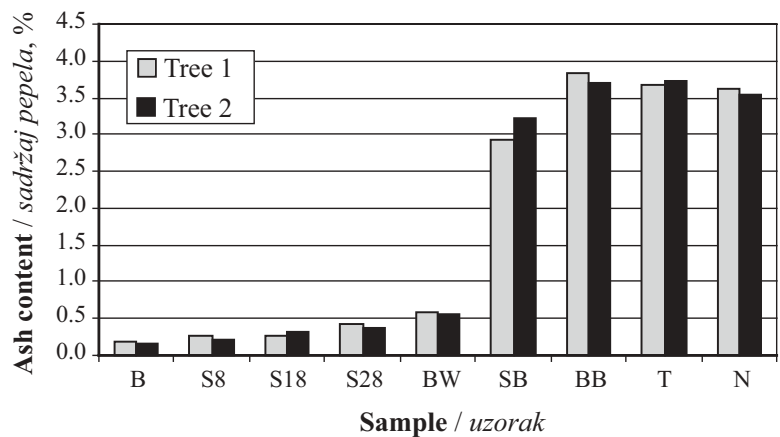

Figure 1 Ash content in larch samples of both trees (B - stemwood at base $(20 \mathrm{~cm}), \mathrm{S} 8$ - stemwood at $8 \mathrm{~m}, \mathrm{~S} 18$ stemwood at $18 \mathrm{~m}, \mathrm{~S} 28$ - stemwood at $28 \mathrm{~m}, \mathrm{BW}$ - branch wood, SB - stemwood bark, BB - branch wood bark, T twigs, N - needles)

Slika 1. Sadržaj pepela u uzorcima iz oba stabla ariša (B - stablo u bazi, $20 \mathrm{~cm}, \mathrm{~S} 8$ - stablo na visini $8 \mathrm{~m}, \mathrm{~S} 18$ - stablo na visini $18 \mathrm{~m}, \mathrm{~S} 28$ - stablo na visini $28 \mathrm{~m}$, BW - drvo grane, SB - kora stabla, BB - kora grane, $\mathrm{T}$ - sitne grane, $\mathrm{N}$ iglice)

with increasing height of the trunks. Characteristic ash concentrations were between 0.15 and $0.43 \%$ and there was little difference between both trees. Branch wood contained slightly more ash than the trunk parts. Typical values ranged from 0.5 to $0.6 \%$. In contrast to the wood samples, bark, twigs and needles contained much more inorganic material. They had similar ash concentrations, all of them approaching or exceeding $3 \%$.

The corresponding values are presented in Figure 1. FTIR spectra of wood and bark ashes showed practically no difference. There were intensive carbonate peaks with wave numbers of about 1440, 876 and 710 $\mathrm{cm}^{-1}$. Silicate peak was also visible at $1050 \mathrm{~cm}^{-1}$; however its intensity was poor. In contrast, twigs and needles gave spectra with much more abundant silicate peaks indicating that the concentrations of silicates increased from the trunk towards outer tree parts, such as bark, branches, twigs and needles.

FTIR spectra of ashes from stemwood, twigs and needles are presented in Figures 2, 3 and 4.

Distributions of N, P and S in different tree tissues showed similar pattern. Typically concentrations of $\mathrm{N}$ and $\mathrm{P}$ increased with tree heights, while the quantity of S remained more or less constant. Bark samples, twigs and needles proved to have relatively rich content of $\mathrm{N}$ and $\mathrm{P}$, compared to the stemwood and branch wood. The highest average concentrations of all three elements were found in needles. They approached $2 \%$ $(w / w)$ for $\mathrm{N}, 3 \mathrm{~g} / \mathrm{kg}$ for $\mathrm{P}$ and $1.7 \mathrm{~g} / \mathrm{kg}$ for $\mathrm{S}$, which is in good agreement with the results reported by Paques (1994) and Alriksson et al. (1998).

Distributions of N, P and S contents in different materials of both larch trees are presented in Figures 5 , 6 and 7.

$\mathrm{K}$ and $\mathrm{Mg}$ exhibited practically the same concentration behavior as $\mathrm{N}$ and $\mathrm{P}$, while $\mathrm{Ca}$ strongly predominated in bark samples, where the measured values ranged between 14 and $16 \mathrm{~g} / \mathrm{kg}$. The contents of $\mathrm{Ca}$, $\mathrm{Mg}$ and $\mathrm{K}$ in needles were close to $8 ; 1.5$ and $3 \mathrm{~g} / \mathrm{kg}$, which partly corresponded to the results published by 


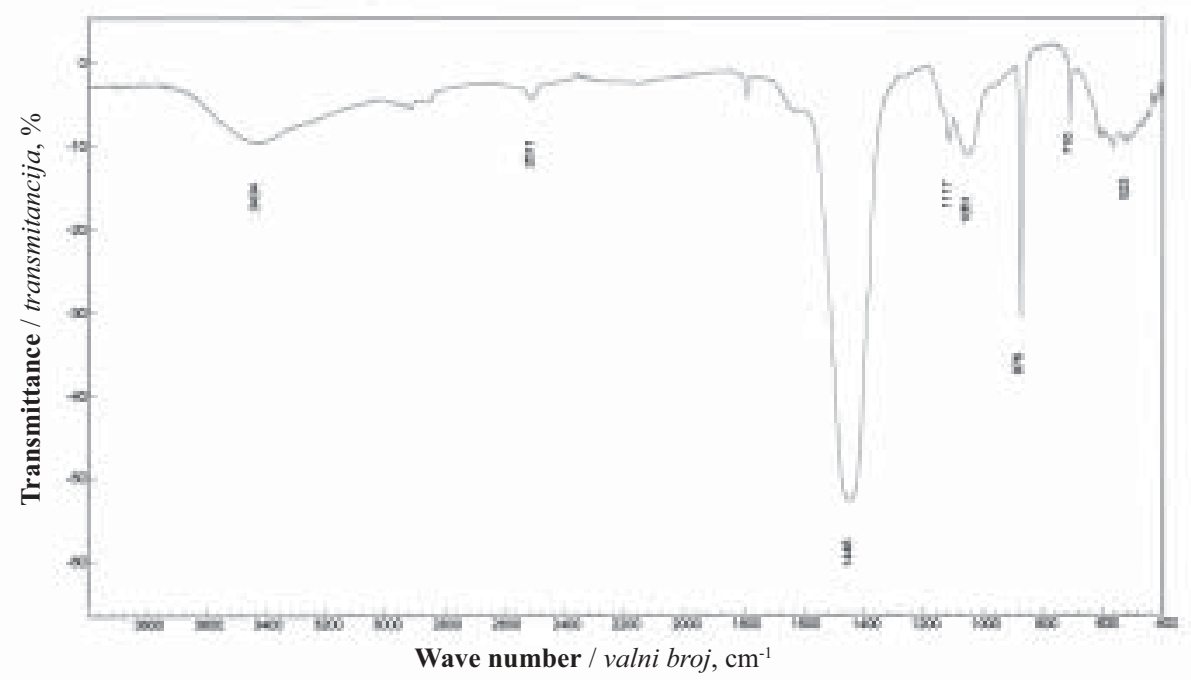

Figure 2 FTIR spectra of stemwood ash Slika 2. FTIR spektar pepela od stabla

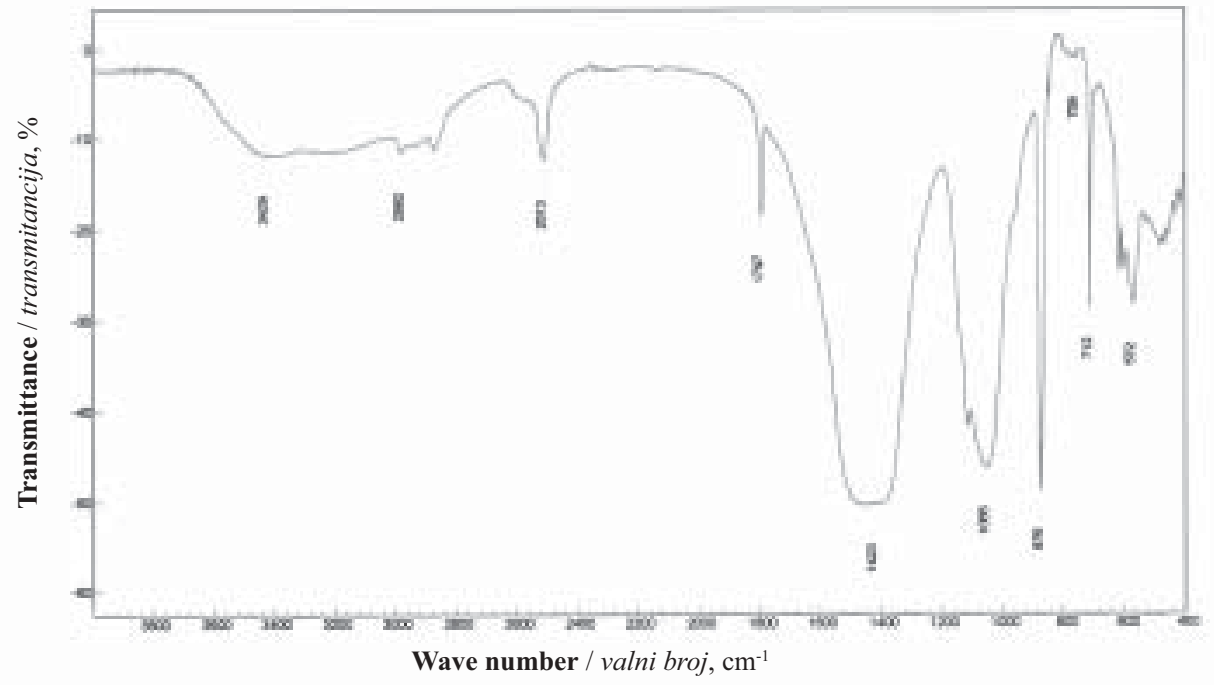

Figure 3 FTIR spectra of ash from twigs

Slika 3. FTIR spektar pepela od sitnih grana

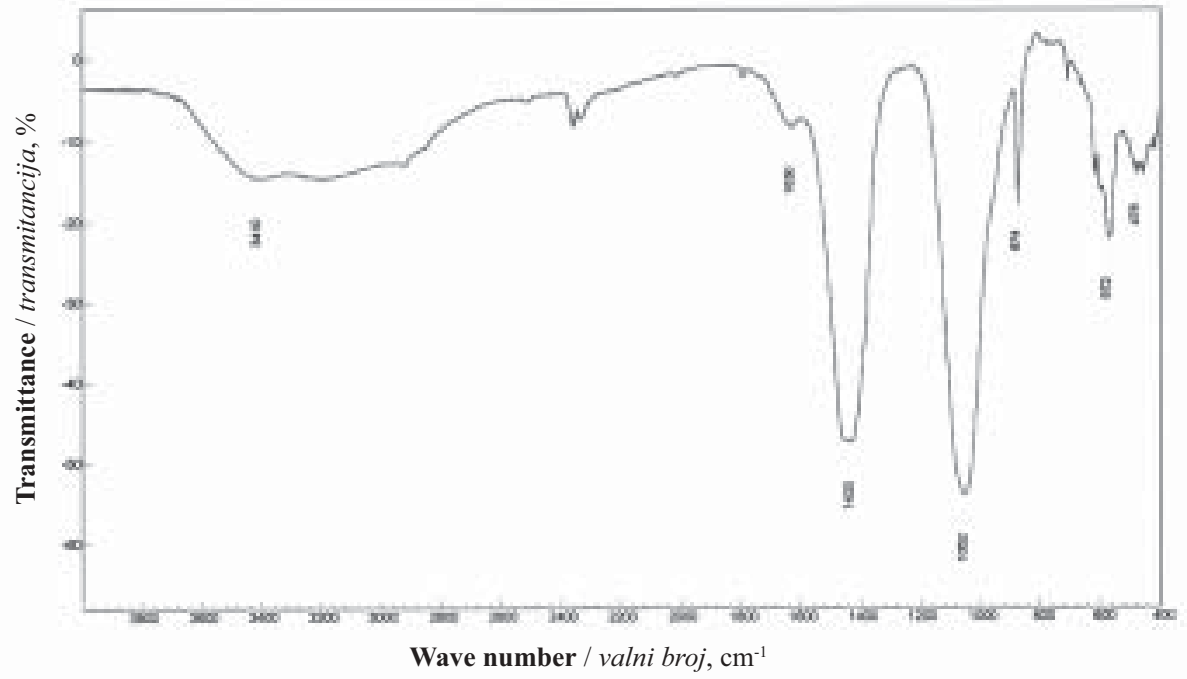

Figure 4 FT-IR spectra of ash from needles

Slika 4. FT-IR spektar pepela od iglica 


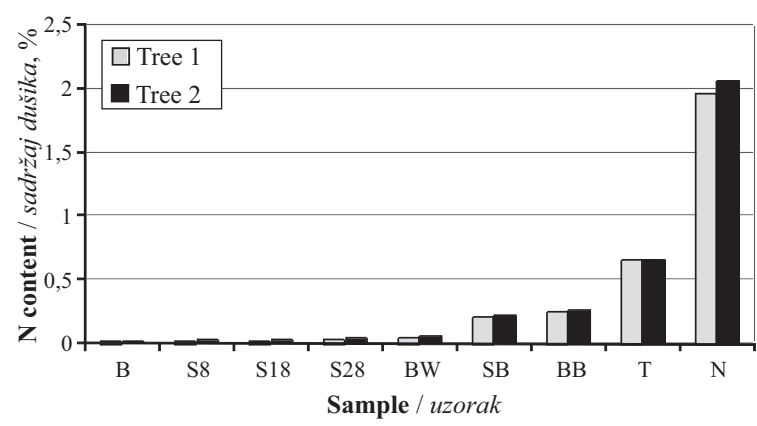

Figure 5 Nitrogen $(\mathrm{N})$ content of larch wood tissues Slika 5. Sadržaj dušika $(\mathrm{N})$ u drvnim tkivima ariša

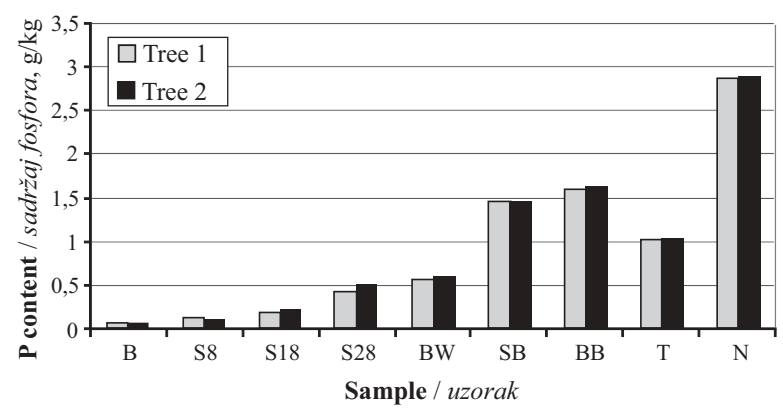

Figure 6 Phosphorus (P) content of larch wood tissues Slika 6. Sadržaj fosfora $(\mathrm{P}) \mathrm{u}$ drvnim tkivima ariša

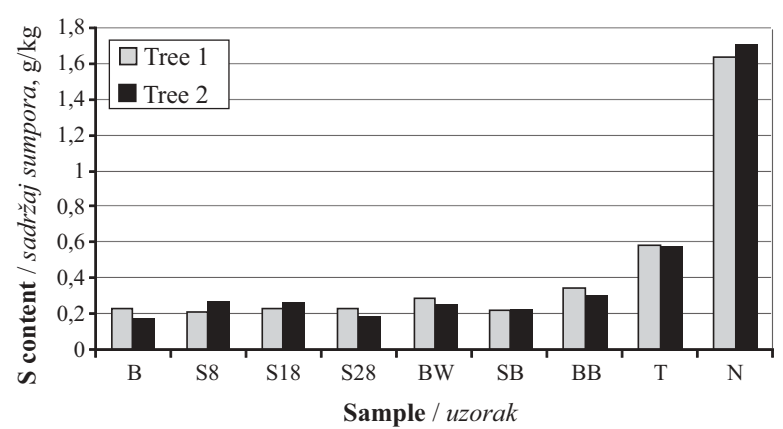

Figure 7 Sulphur (S) content of larch wood tissues Slika 7. Sadržaj sumpora (S) u drvnim tkivima ariša

Paques (1994), Myre et al. (1996) and Alriksson et al. (1998), where the presented foliar concentrations of $\mathrm{Ca}$ and $\mathrm{Mg}$ in different larch species were similar, but those of $\mathrm{K}$ were typically somewhat higher.

According to our results, there was no significant difference between the two analyzed larch trees as far as the distributions of the six macro elements in various tree tissues are concerned. and 10

$\mathrm{K}, \mathrm{Ca}$ and $\mathrm{Mg}$ contents are shown in Figures 8, 9

Distribution patterns of measured microelements $\mathrm{Ni}, \mathrm{Zn}, \mathrm{Mn}, \mathrm{Fe}, \mathrm{Cu}, \mathrm{Al}$ and $\mathrm{Co}$ within different anatomical parts of both larch trees were highly variable. Some similarity was observed in case of $\mathrm{Zn}$ and $\mathrm{Mn}$, as both elements prevailed in bark samples where their concentrations amounted to about 45 and $270 \mathrm{mg} / \mathrm{kg}$, while needles contained surprisingly lower quantities and namely about $25 \mathrm{mg} / \mathrm{kg}$ of $\mathrm{Zn}$ and between 25 and $50 \mathrm{mg} / \mathrm{kg}$ of $\mathrm{Mn}$. The concentrations of Mn were substantially lower, compared to the results of a similar study published by Myre et al. while values for $\mathrm{Zn}$ were quite comparable. The distribution of $\mathrm{Zn}$ and $\mathrm{Mn}$

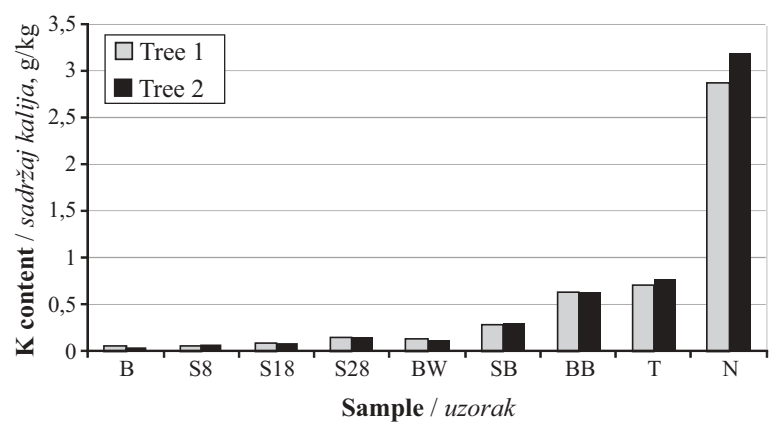

Figure 8 Potassium $(\mathrm{K})$ content of larch wood tissues Slika 8. Sadržaj kalija (K) u drvnim tkivima ariša

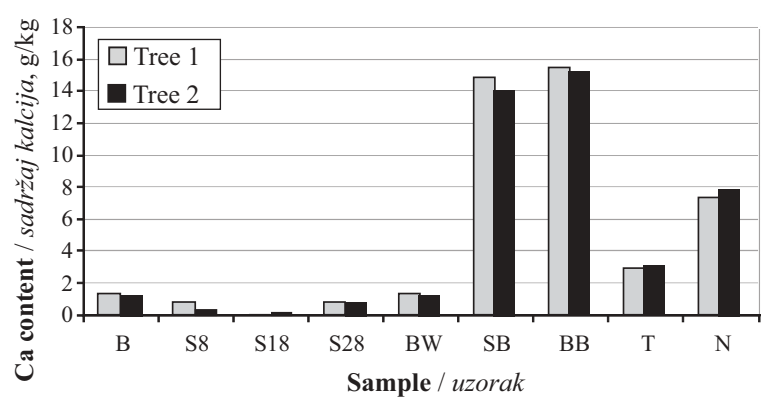

Figure 9 Calcium $(\mathrm{Ca})$ content of larch wood tissues Slika 9. Sadržaj kalcija (Ca) u drvnim tkivima ariša

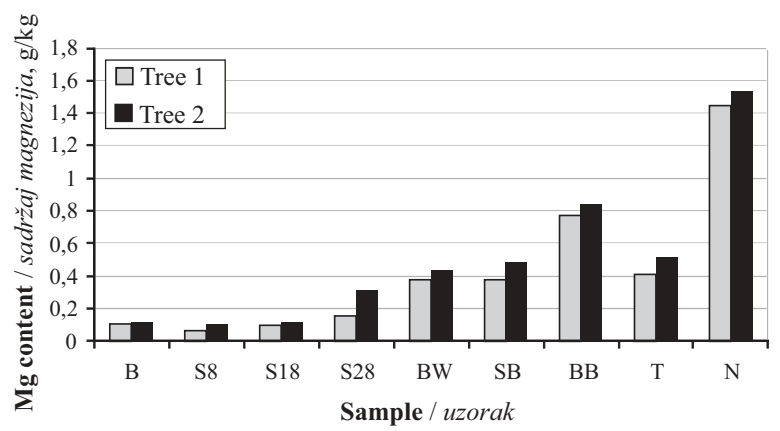

Figure 10 Magnesium $(\mathrm{Mg})$ content of larch wood tissues Slika 10. Sadržaj magnezija $(\mathrm{Mg})$ u drvnim tkivima ariša

concentrations in different larch tissues are presented in Figures 11 and 12.

$\mathrm{Ni}, \mathrm{Fe}, \mathrm{Al}$ and $\mathrm{Co}$ predominated in needles where average concentrations amounted to about $1 ; 135 ; 200$ and $0.6 \mathrm{mg} / \mathrm{kg}$. Surprisingly high contents of $\mathrm{Ni}, \mathrm{Cu}$ and $\mathrm{Fe}$ were determined in stemwood base samples (about $0.6 ; 12.5$ and $30 \mathrm{mg} / \mathrm{kg}$ ), which was not the case with other elements. Significant is also the fact that the lowest overall concentrations were measured for $\mathrm{Ni}$, $\mathrm{Cu}$ and $\mathrm{Co}$.

The results for $\mathrm{Cu}$ and $\mathrm{Fe}$ are in good agreement with the values obtained by Bending and Moffat (1999) in their systematic studies of foliar nutrients in Japanese larch. Average values of $\mathrm{Ni}, \mathrm{Fe}, \mathrm{Cu}, \mathrm{Al}$ and $\mathrm{Co}$ analyses of larch wood tissues are presented in Figures 13 to 17 .

It has to be emphasized that the repeatability of all macro and micro element determinations was very high due to efficient homogenization of samples before the analyses. Parallel measurements never differed more than $11 \%$ from each other, even in case of low concentration elements, such as $\mathrm{Co}, \mathrm{Cu}$ and $\mathrm{Ni}$. The 


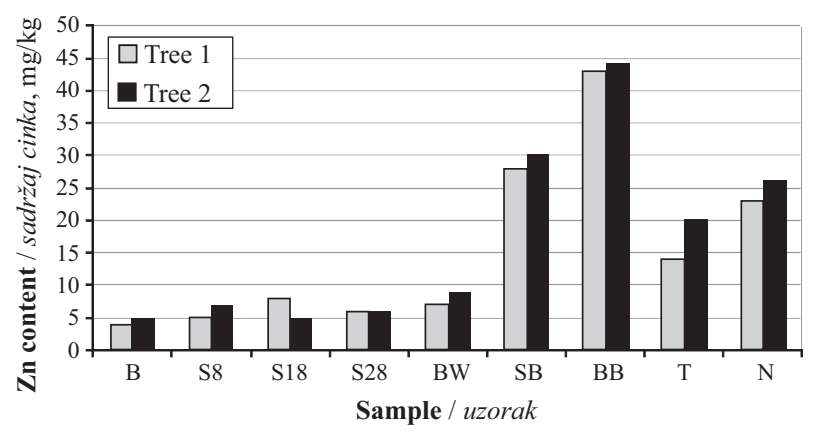

Figure $11 \mathrm{Zinc}(\mathrm{Zn})$ content of larch wood tissues Slika 11. Sadržaj cinka (Zn) u drvnim tkivima ariša

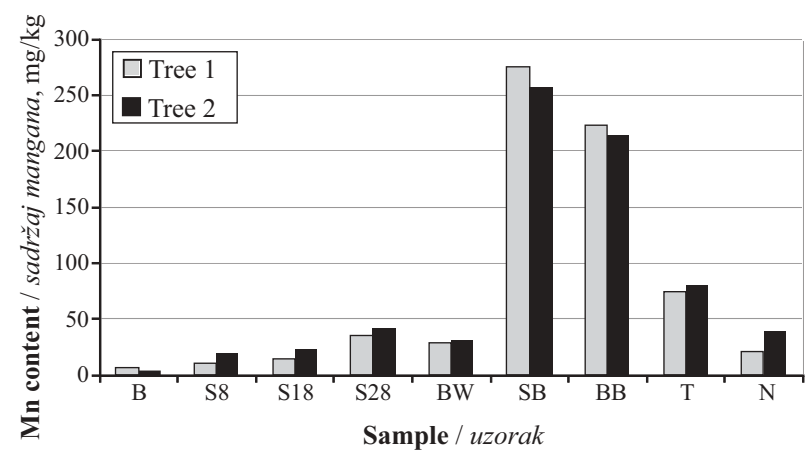

Figure 12 Manganese (Mn) content of larch wood tissues Slika 12. Sadržaj mangana (Mn) u drvnim tkivima ariša

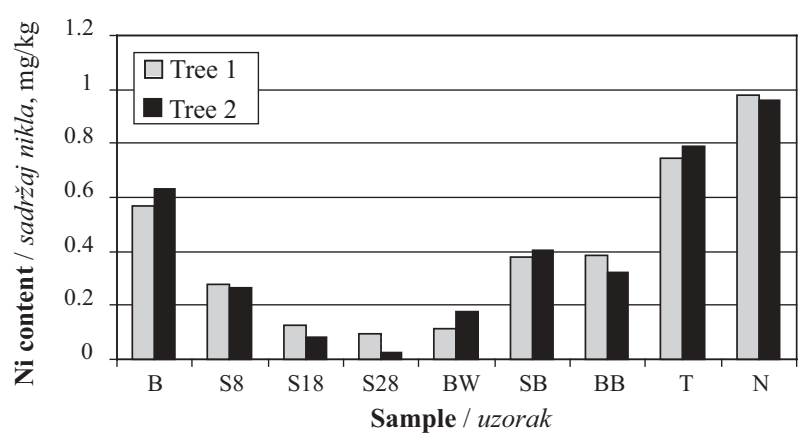

Figure 13 Nickel (Ni) content of larch wood tissues Slika 13. Sadržaj nikla (Ni) u drvnim tkivima ariša

results indicated that the two examined larch trees exhibited surprisingly high similarity in their mineral structure and showed no pronounced deficiency in the content of most analyzed elements, which corresponded to their healthy condition.

\section{CONCLUSIONS}

\section{ZAKLJUČCl}

By determination of macro and micro nutrients in different larch tissues, a typical distribution pattern was obtained for each element. Most elements such as $\mathrm{N}, \mathrm{P}, \mathrm{S}, \mathrm{K}, \mathrm{Mg}, \mathrm{Ni}, \mathrm{Fe}, \mathrm{Al}$ and Co predominated in needles, while $\mathrm{Ca}, \mathrm{Zn}$ and $\mathrm{Mn}$ were most abundant in bark. External tree parts as for example bark, branches, twigs and needles had much higher inorganic contents than stemwood where the concentrations of individual elements increased with height.

According to FTIR spectra many elements in stemwood and bark were bound as carbonates in contrast to twigs and needles where silicates prevailed.

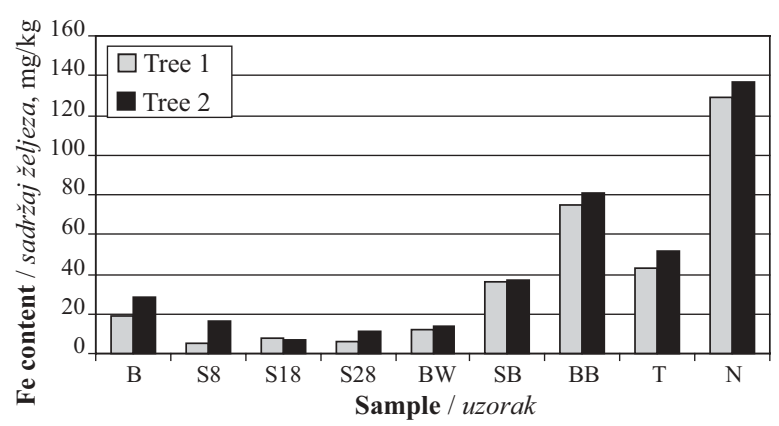

Figure 14 Iron (Fe) content of larch wood tissues Slika 14. Sadržaj željeza (Fe) u drvnim tkivima ariša

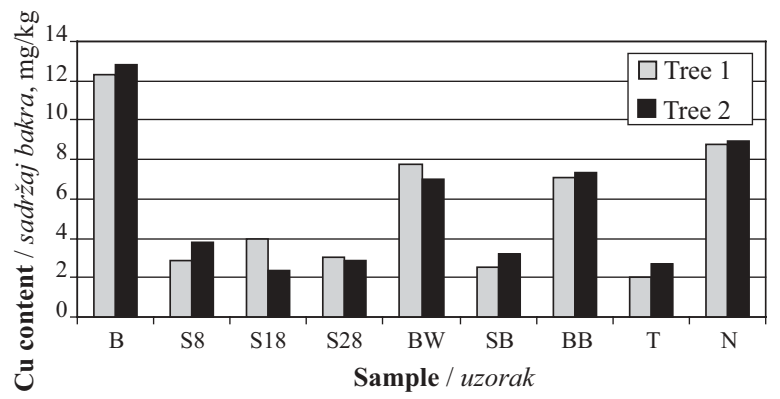

Figure 15 Copper $(\mathrm{Cu})$ content of larch wood tissues Slika 15. Sadržaj bakra $(\mathrm{Cu})$ u drvnim tkivima ariša

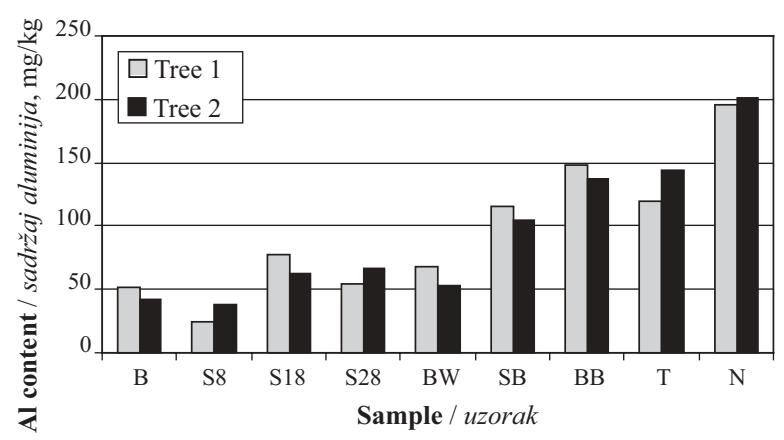

Figure 16 Aluminium (Al) content of larch wood tissues Slika 16. Sadržaj aluminija (Al) u drvnim tkivima ariša

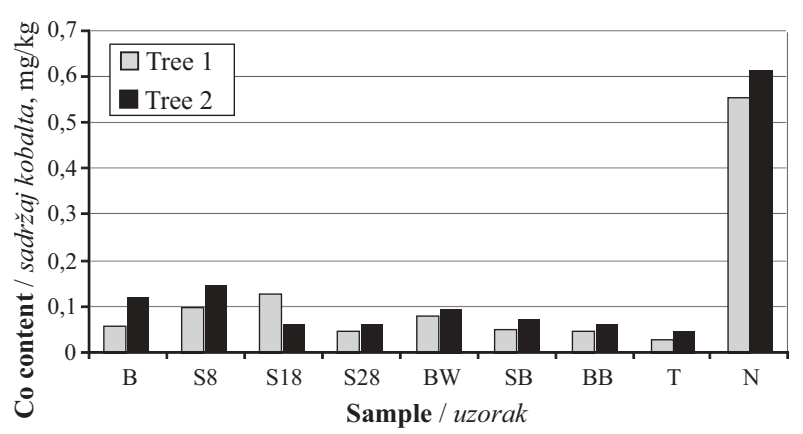

Figure 17 Cobalt (Co) content of larch wood tissues

Slika 17. Sadržaj kobalta $(\mathrm{Co})$ u drvnim tkivima ariša

It was established by foliar analyses that nutrient status of both trees was good as most of the measured elements exhibited optimal or close to optimal values.

\section{REFERENCES}

\section{LITERATURA}

1. Alriksson, A.; Eriksson, H.M., 1998: Variations in mineral nutrient and $\mathrm{C}$ distribution in the soil and vegetation compartments of five temperate tree species in NE Sweeden, Forest Ecology and Management 108:261-273, http://dx.doi.org/10.1016/S0378-1127(98)00230-8. 
2. Antonović. A.; Jambreković, V.; Pervan, S.; Ištvanić, J.; Moro, M.; Zule, J., 2007: Utjecaj lokaliteta uzorkovanja na grupni kemijski sastav bijeli bukovine (Fagus sylvatica L.), Drvna Industrija 58 (3):119-125.

3. Antonović, A.; Jambreković, V.; Franjić, J.; Španić, N.; Pervan, S.; Ištvanić, J.; Bublić, A., 2010: Influence of sampling location on content and chemical composition of the beech native lignin (Fagus sylvatica L.), Periodicum Biologorum 112 (3):327-332.

4. Bujas, N., 1998: Prilog poznavanju kemizma kore bukovine, Drvna industrija 49 (3): 145-150.

5. Bending, N. A. D.; Moffat, A.J., 1999: Tree performance on minespoils in South Wales coalfield, Journal of Applied Ecology, 36: 784-797, http://dx.doi.org/10.1046/j.1365-2664.1999.00444.x

6. Cape, J. N. F.; Freer-Smith, P-H.; Paterson, I.S.; Parkinson, J.A.; Wolfenden, J., 1990: The nutritional status of Picea abies (L.) Karst. across Europe and implications for forest decline, Trees 4:211-224, http://dx.doi.org/10.1007/BF00225318.

7. Ditmarova, L.; Kmet, J.; Ježik, M.; Valka, J., 2007: Mineral nutrition in relation to the Norway spruce forest decline in the region Horny Spiš (Northern Slovakia), Journal of Forest Science 53 (3):93-100.

8. Ericsson, A.; Norden, L.G.; Näsholm, T.; Walheim, M., 1993: Mineral nutrient imbalance and arginine concentrations in needles of Picea abies (L.) Karst. from two areas with different levels of airborne deposition, Trees 8:67-74, http://dx.doi.org/10.1007/BF00197683

9. Eriksson, H. M.; Rosen, K., 1994: Nutrient distribution in a Swedish tree species experiment, Plant and Soil 164: 51-59, http://dx.doi.org/10.1007/BF00010110

10. Fengel, D.; Wegener, G., 1989: Wood chemistry, ultrastructure, reactions, Walter de Gruyter, Berlin-New York, $812 \mathrm{pp}$.

11. Henry, P. H.; Blazich, F.A.; Hinesley, L. E.; Wright, R.D., 1992: Nitrogen nutrition of containerized Eastern Redcedar. I. Growth, mineral nutrient concentrations and carbohydrate status, J. Amer. Soc. Hort. Sci. 117 (4): 563-567, http://dx.doi.org/10.1111/j.1399-3054.1979.tb02599.x.

12. Ingestad, T., 1979: Mineral nutrient requirements of $P i$ nus silvestris and Picea abies seedlings, Physiol. Plant 45: 373-380.

13. Katzensteiner, K.; Glatzel, G.; Kazda, M.; Sterba, M., 1992: Effects of air pollutants on mineral nutrition of Norway spruce and revitalization of declining stands in Austria, Water, Air and Soil Pollution 61: 309-322, http://dx.doi.org/10.1007/BF00482613.

14. Komlenović, N.; Orlić, S.; Rastovski, P., 1995: Growth and biomass production of six coniferous species in fern and heath areas of Croatia, Šumarski list 119 (5/6):169178.

15. Leyton, L., 1957: The mineral nutrient requirements of forest trees, The Ohio Journal of Science 57 (6):337345.

16. Mandre, M.; Kuznetsova, T., 2004: Conditions for mineral nutrition of conifers on reclaimed oil shale mine sites, Forestry Studies/Metsanduslikud uurimused 41:17-26.

17. Merilä, P.; Derome, J., 2008: Relationships between needle nutrient composition in Scots pine and Norway spruce stands and the respective concentrations in the organic layer and in percolation water, Boreal Environment Research 13 (suppl. B):35-47.

18. Myre, R.; Camiré, C., 1994: Distribution de P, K, Ca, $\mathrm{Mg}, \mathrm{Mn}$ et $\mathrm{Zn}$ dans la tige des mélèzes européen et laricin, Annales des Sciences Forestieres, 51(2):121-134, http://dx.doi.org/10.1051/forest:19940203.

19. Myre, R.; Camiré, C., 1996: The effect of crown position and date of sampling on biomass, nutrient concentrations and contents of needles and shoots in European larch, Trees 10: 339-350, http://dx.doi.org/10.1007/BF02340781.

20. Pâques, L. E., 1994: Relationship between foliar nutrient concentrations and growth of hybrid larch (LarixX erurolepis Henry), Forest Ecology and Management, 63:153167, http://dx.doi.org/10.1016/0378-1127(94)90108-2.

21. Raven, P. H.; Evert, R. F.; Eichhorn, S.E., 2005: Biology of plants, W.H Freeman, New York, 944 pp.

22. Rowell, R. M., 2005: Handbook of Wood Chemistry and Wood Composites. Boca Raton, Fla., CRC Press, 504 pp.

23. Stelzer, R.; Holste, R.; Groth, M.; Schmidt, A., 1993: Xray microanalytical studies on mineral concentrations in vacuoles of needle tissues from Larix decidua (L.) Mill., Botanica Acta.106 (4):325-330.

24. Stenius, P. (ed.), 1999: Papermaking Science and Teschnology, Book 3: Forest products chemistry, Gummerus Printing, Jyväskylä, Finland, 350 pp.

\section{Corresponding address:}

JANJA ZULE, Ph.D.

Pulp and Paper Institute

Bogišičeva 8

SI-1000 Ljubljana, SLOVENIA

e-mail: janja.zule@icp-lj.si 